\title{
UPAYA MENCEGAH DAMPAK NEGATIF SOSIAL MEDIA DENGAN LAYANAN INFORMASI MELALUI MEDIA VISUAL PADA SISWA KELAS XI SEKOLAH MENENGAH ATAS NEGERI 1 PEMANGKAT KABUPATEN SAMBAS
}

\author{
Toni Elmansyah ${ }^{1)}$ \\ 1) Dosen Bimbingan dan Konseling IKIP-PGRI Pontianak, Pontianak, Indonesia \\ Email:merah.semangka@gmail.com
}

\begin{abstract}
Abstrak. Tujuan dalam penelitian ini adalah: mendeskripsikan perencanaan layanan informasi dengan media visual oleh guru Bimbingan dan Konseling untuk mencegah dampak negatif Sosial Media, Mendeskripsikan pelaksanaan layanan informasi dengan media visual oleh guru Bimbingan dan Konseling untuk mencegah dampak negatif Sosial Media pada siswa, Mendeskripsikan perilaku siswa setelah diberikan layanan informasi untuk mencegah dampak negatif Sosial Media dengan media visual.metode yang digunakan dalam penelitian ini adalah metode penelitian tindakan. Subjek penelitian ini berjumlah 33 orang. Hasil penelitian ini Perencanaan layanan informasi dengan menggunakan media visual oleh guru Bimbingan dan Konseling untuk mencegah dampak negatif Sosial Media, meliputi; merancang program bimbingan dan konseling, memilih dan menentukan jenis bimbingan yang tepat. Pelaksanaan layanan informasi dengan menggunakan media visual meliputi penginformasian materi bimbingan, pemilihan materi dan penjelasan yang cocok dengan siswa, penekanan terhadap pembahasan yang dianggap penting dan penjelasan tentang keterkaitan antar materi layanan informasi, evaluasi berupa penilaian di akhir proses pemberian layanan informasi dan tindak lanjut. Terjadi peningkatan perilaku siswa setelah diberikan layanan informasi yakni dengan pencapaian persentase pada siklus I sebesar 43,33\% dan meningkatkan menjadi 83,33\% pada siklus II.
\end{abstract}

Kata Kunci: Layanan Informasi; Dampak Negatif Media Sosial; Media Visual

\section{Pendahuluan}

Arus perkembangan teknologi ini bagaimana pun tak akan bisa kita bendung, sebagian besar anak dan remaja saat ini telah familiar dengan internet yang menghadirkan berbagai informasi dan beragam cara berkomunikasi secara jarak jauh. Banyak hal positif sebenarnya yang dapat dirasakan dengan adanya perkembangan teknologi seperti ini, terutama di bidang pendidikan. Melalui Sosial Media (social media), siswa dapat membuat komunitas mata pelajaran sebagai sarana diskusi tentang materi pelajaran atau dapat digunakan sebagai sarana untuk berkomunikasi secara akrab antara guru dengan siswa. Jejaring sosial tersebut bergam jenisnya mulai dari facebook, twitter, Instagram, Whatsup, Snapchat, Blackberry Messengger.

Pada umumnya media sosial tersebut mampu menghipnotis ribuan remaja yang di dunia ini, dengan waktu singkat alat komunikasi dunia maya ini sudah mampu menarik minat masyarakat untuk mencobanya. Tak segansegan para orang tua pun ikut terhipnotis dalam pergaulan dunia maya tersebut.Dampak positif dan negatif pasti akan kita temukan dalam melakukan atau berhubungan di dunia maya dengan jejaring internet tersebut.
Pada dasarnya, Sosial Media ini dapat memotivasi diri kita sendiri agar lebih baik dan tanpa merugikan pendidikan yang telah kita dapatkan, jika kita mampu memanfaatkan dunia jejaring tersebut dengan arif yang berdasarkan atas norma-norma yang ada. Sehingga tidak akanada lagi orang yang dirugikan oleh Sosial Media ini dan justru akan berdampak positif bagi kita.

Peran guru Bimbingan dan Konseling dalam upaya mengatasi dampak negatif Sosial Media ini sangat penting. Tugas guru bimbingan dan konseling, terutama dalam upaya mencegah dampak negatif Sosial Media pada siswa, merupakan salah satu yang penting untuk dilakukan, karena dalam bimbingan dan konseling terdapat tujuan yang terkait dengan aspek pribadi-sosial siswa yang berkenaan dengan hal tersebut. Hal ini dikemukakan oleh Syamsu Yusuf dan A. Juntika Nurihsan [1] yaitu: "Memiliki komitmen yang kuat dalam mengamalkan nilai-nilai keimanan dan ketaqwaan kepada Tuhan Yang Maha Esa, baik dalam kehidupan pribadi, keluarga, pergaulan dengan teman sebaya, sekolah, tempat kerja, maupun masyarakat pada umumnya".

Tujuan ini menjadikan bimbingan untuk mengatasi dampak negatif Sosial Media, melalui pemberian layanan informasi menjadi elemen penting dalam pembinaan 
kepribadian siswa. Diperlukan adanya suatu media yang tepat yang mengakomodasi pencapaian tujuan agar siswa dapat memahami dan menghayati dampak negatif Sosial Media, bagi orang tua siswa, sekolah, masyarakat dan utamanya bagi siswa itu sendiri. Thursan Hakim [2] bahwa: "Salah satu faktor yang mempengaruhi keberhasilan pendidikan adalah adanya penggunaan media yang tepat dengan tahap-tahap yang jelas dan dilaksanakan secara sistematis". Selain itu, penerapan media yang tepat, akan menjadikan proses bimbingan berjalan efekif dan efisien.

\section{METODE}

Metode yang digunakan dalam penelitian ini adalah metode penelitian tindakan. Adapun bentuk penelitian yang digunakan adalah penelitian tindakan kelas terapan.Dalam bimbingan dan konseling, penelitian tindakan kelas, disebut dengan penelitian tindakan bimbingan dan konseling (PTBK). Adapun tahapan pelaksanaan dalam penelitian ini adalah perencanaan, tindakan, pengamatan, refleksi [3]. Subjek dalam penelitian ini berjumlah 33 orang. Teknik pengumpulan data menggunakan Alat pengumpulan data menggunakan observasi dan komunikasi langsung. Alat Pengumpulan data menggunakan pedoman onservasi dan panduan wawancara.

\section{HASIL DAN PEMBAHASAN}

Berdasarkan hasil penelitian diketahui bahwa layanan informasi telah dilaksanakan oleh guru Bimbingan dan Konseling untuk mencegah dampak negatif sosial media pada siswa meliputi kegiatan; merancang program bimbingan dan konseling, memilih dan menentukan jenis layanan yang tepat, menetapkan jenis layanan yang akan diberikan, menyusun satuan layanan berkenaan dengan materi, serta menyiapkan media yang akan digunakan. Pelaksanaan Layanan informasi telah berjalan dengan optimal, hal ini ditandai dengan; perencanaan yang baik, penggunaan media visual dalam penyampaian, serta penerapan metode yang sesuai dengan perkembangan siswa. Adapun perilaku siswa setelah diberikan layanan informasi untuk mencegah dampak negatif sosial mediadengan media visual di kelas XI Sekolah Menengah Atas Negeri 1 Pemangkat Kabupaten Sambas mengalami perubahan ke arah yang lebih baik, hal ini disebabkan: a) Siswa tetap mampu berkomunikasi dengan menggunakan bahasa yang baik saat bergaul secara langsung di lingkungan sekolah maupun bergaul dengan temannya lewat sosial media; b) Siswa mampu menghindarkan diri dari perbuatan-perbuatan yang merusak moral seperti membuka situs pornografi, meskipun situs-situs tersebut semakin marak dipromosikan lewat sosial media; c) Perilaku sosial siswa tetap tumbuh dan berkembang, seperti kebersamaan, kepedulian, toleransi antar sesama, sopan santun dan saling menghormati antar sesama; d) Kelemahannya adalah kedisiplinan siswa terhadap peraturan sekolah dalam hal membawa HP dan penggunaan waktu belajar di rumah masih rendah, sehingga prestasi belajar siswa menurun.
Berdasarkan hasil penelitian tentang perubahan perilaku siswa berkenaan dengan dampak negatif sosial media setelah pelaksanaan layanan informasi, maka dapat dikatakan bahwa perilaku siswa setelah diberikan layanan informasi untuk dampak negatif Sosial Mediadengan media visual di kelas XI Sekolah Menengah Atas Negeri 1 Pemangkat Kabupaten Sambas mengalami perubahan ke arah yang lebih baik. Hal ini disebabkan, pada tindakan siklus I, kualitas perilaku secara keseluruhan mencapai $43,33 \%$ dan mengalami peningkatan pada siklus II menjadi $83,33 \%$.

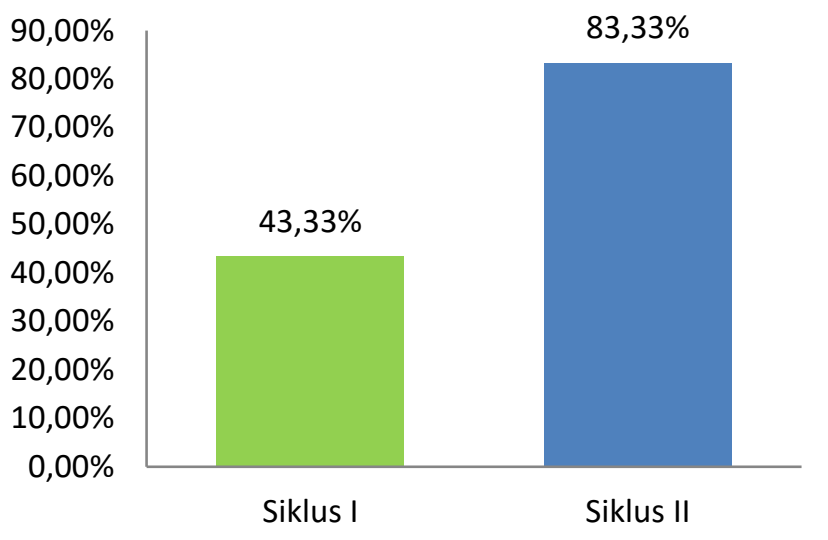

Grafik 1 Rekapitulai Perubahan Perilaku Siswa Berkenaan dengan Dampak Negatif Sosial Media setelah Pelaksanaan Layanan Informasi

\section{KESIMPULAN DAN SARAN}

Perencanaan layanan informasi dengan menggunakan media visual oleh guru Bimbingan dan Konseling untuk mencegah dampak negatif Sosial Media, meliputi; merancang program bimbingan dan konseling, memilih dan menentukan jenis bimbingan yang tepat dengan materi dalam hal ini adalah bimbingan sosial; menetapkan jenis layanan yang akan diberikan dalam hal ini layanan informasi, menyusun satuan layanan bimbingan yang berkenaan dengan materi, menyiapkan materi layanan informasi, menyiapkan sumber-sumber materi dan media visual. Pelaksanaan layanan informasi dengan menggunakan media visual oleh guru Bimbingan dan Konseling untuk mencegah dampak negatif Sosial Media pada siswa kelas XI Sekolah Menengah Atas Negeri 1 Pemangkat Kabupaten Sambas, meliputi: penginformasian materi bimbingan, pemilihan materi dan penjelasan yang cocok dengan siswa, penekanan terhadap pembahasan yang dianggap penting dan penjelasan tentang keterkaitan antar materi layanan informasi, evaluasi berupa penilaian di akhir proses pemberian layanan informasi dan tindak lanjut. Perilaku siswa setelah diberikan layanan informasi untuk mencegah dampak negatif sosial media dengan media visual di kelas XI Sekolah Menengah Atas Negeri 1 Pemangkat Kabupaten Sambas mengalami perubahan ke arah yang lebih baik dengan pencapaian persentase pada siklus I sebesar $43,33 \%$ dan meningkatkan menjadi $83,33 \%$ pada siklus II. 
Saran; guru BK perlu secara rutin melaksanakan layanan informasi, melakukan penilaian terhadap layanan yang diberikan. Sekolah dapat mengambil tindakan tegas terhadap penerapan tata tertib terutama menggunakan media sosial, oran tua siswa dapat melakukan pengawasan terhadap penggunaan media sosial anaknya.

\section{DAFTAR PUSTAKA}

[1] Yusuf, S dan Nurihsan, J, A (2009). Landasan Bimbingan dan Konseling. Bandung: Remaja Rosdakarya.

[2] Hakim, T (2000).Cara Belajar yang Efektif. Jakarta: Prenada Media.

[3] Arikunto, Suharsimi (2000). Prosedur Penelitian: Suatu Pendekatan Praktek. Jakarta: Rineka Cipta. 